\title{
THE QUALIFICATION OF PSYCHIATRISTS AS EXPERTS IN LEGAL PROCEEDINGS
}

\author{
Israel Strauss*
}

On November I, rg28, the Honorable Benjamin N. Cardozo, then the Chief Judge of the Court of Appeals of New York State, addressed the New York Academy of Medicine on "What Medicine Can Do For Law." In this address he pointed to the unsatisfactory distinction in the law of homicide, between murder in the first and second degrees, especially the rôle which premeditation is supposed to play in distinguishing these two degrees of homicide. In regard to this he stated, "The present distinction is so obscure that no jury hearing it for the first time can fairly be expected to assimilate and understand it. I am not at all sure that I understand it myself after trying to apply it for many years and after diligent study of what has been written in the books. Upon the basis of this fine distinction with its obscure and mystifying psychology, scores of men have gone to their death." He also dwelt upon the law defining and governing mental irresponsibility, which is based in our state upon the formula adopted in M'Naghten's Case, and he referred to the principle that morbid propensity or irresistible impulse is not to be considered as a defense. Later in his talk he said, "Everyone concedes that the present definition of insanity has little relation to the truths of mental life."

In an attempt to see what could be done towards remedying these conditions the Bar Association of the City of New York appointed a committee. At the same time, upon request from the Bar Association, a committee was formed by the New York Academy of Medicine. Members of the faculty of the Columbia School of Law were also invited to participate in the conferences. The Carnegie Foundation provided funds to assist in this endeavor. These committees held a number of meetings but found that it was practically impossible at this time to bring about a change in the definition of legal responsibility in this state or upset the definition of premeditation, as laid down in the opinions of the New York Court of Appeals, or to change the attitude of the law regarding morbid propensity and irresistible impulse.

The committees decided that to bring about changes of this kind meant a long period of education, not only of the legal profession but of the public as well. It was

- A.M., MD. Attending Neurologist, The Mount Sinai Hospital, New York City. Chairman, Committee on Medical Jurisprudence of the New York Academy of Medicine. Past President, the American Neurological Association and the Association for Research of Nervous and Mental Disease. 
finally agreed that while the substance of the law itself could not be changed a change in procedure might be brought about, through which the services of psychiatry could be utilized in the practice and application of the law and its procedure as it exists. It was then decided that a survey be made of lunacy commissions in criminal cases, in one of our large cities covering a period of five years from 1926 to 1930 inclusive, in order to ascertain in how many of these commissions the services of a psychiatrist had been used.

These commissions are appointed under the authority of Section 658 of the New York Code of Criminal Procedure which provides that "when a defendant pleads insanity ... the court in which the indictment is pending, instead of proceeding with the trial of the indictment, may appoint a commission of not more than three disinterested persons, to examine him and report to the court as to his sanity at the time of the commission of the crime."1 Although the statute does not expressly so provide, it has been held also to authorize the commission to report on the capacity of the defendant to stand trial. Where the defendant is found sane both at the time of the offense and at the time of trial, the court proceeds to the trial of the indictment. Where he is found sane at the time of the trial but insane at the time of the offense, he must be tried nonetheless but the report is available for guidance of the court and of counsel for both prosecution and defense and, if the defendant is destitute, may furnish a basis for the employment of experts by him at the expense of the state. Where the defendant is found insane at the time of trial, provision is made for his commitment until recovery. ${ }^{2}$

The importance of this statute in the administration of criminal justice in New York State can readily be appreciated. ${ }^{3}$ The importance of the personnel of these

${ }^{x}$ The second paragraph of that section specifies the procedure to be followed by the commission as follows:

"The commission must summarily proceed to make their examination. Before commencing they must take the oath prescribed in the Code of Civil Procedure, to be taken by referees. They must be attended by the district attorney of the county, and may call and examine witnesses and compel their attendance. The counsel of the defendant may take part in the proceedings. When the commissioners have concluded their examination they must forthwith report the facts to the court with their opinion thercon."

"For an interpretation of Section 658 and the succeeding provisions relating to the effect of lunacy commissions" reports, see Pcople v. Whitman, 149 Misc. 159, 266 N. Y. Supp. 844 (1933).

${ }^{3}$ Section 658 is not, however, the only provision in the New York statutes providing for examination of the mental condition of accused persons. Section 836 of the Code of Criminal Procedure provides separate procedures for the examination of persons accused of misdemeanors and felonies respectively. Both contemplate commitment of the defendant by the judge to a state hospital for examination and report, but, where a felony is charged, provision is made for further examination by "two physicians, who shall have had at least five years experience in actual practice, at least one of whom shall be a qualified psychiatrist as provided by law." Since no law as yet provides the qualifications of psychiatrists, this last clause remains an empty gesture.

Two other procedures are also provided by statute. Section $3 \mathrm{Y}$ of the Judiciary Law, N. Y. Cons. Luws (Cahill, 1930) c. 31, provides "in a criminal action .... in which the soundness of mind of a person is in issue," the judge may appoint "not more than three disinterested competent physicians" to examine such person. Section 125 of the Mental Hygiene Law, id., c. 36a, provides for the examination, by order of the judge, before or after trial, of any person alleged to be mentally defective, as distinguished from insane, by "two qualified examiners or a qualified examiner and a qualified psychologist." A physician "who has practiced for at least three years "shall be and become a qualified examiner." $\mathrm{A}$ per- 
commissions-" "not more than three disinterested persons"-is equally evident. The courts in actual practice have generally appointed a lawyer, a physician, and a layman; occasionally two lawyers or two laymen.

Consent for such a survey was obtained from the judges of the courts. In fact the judges have supported every movement made by the joint committees to improve the present situation covering criminal code procedure. The result of this survey is not to be regarded as casting any reflection on any of these judges in the choice of physicians, for the reason that they did not have at their disposal a list of qualified psychiatrists but were compelled to use the services of physicians who were recommended to them.or were known to them personally.

The survey revealed that in the course of five years 14,982 felonies and 6,808 misdemeanors were tried. It was also found that 792 lunacy commissions and examiners in mental defect ${ }^{4}$ were appointed. Of the 792 prisoners examined, psychiatric conditions were noted in $5 \mathrm{I} 7$ cases. The appointment of these various commissions required the services of physicians on ro5o occasions. The number of men qualified in psychiatry appointed on these commissions totalled 16 , and these men served on 62 occasions. On a percentage basis, qualified psychiatrists served on 6 per cent of the cases in which this court had to appoint physicians for a psychiatric opinion.

The qualifications of the physicians appointed by the court were determined by reference to the medical directory, wherein a short autobiography of physicians is recorded, the doctor designating his own hospital affiliations and the branch of medicine he practices. As a result of such an investigation it was found that there were appointed physicians specializing in internal medicine 15; surgery 15; gynecology 5; urology 4; pediatrics 6; ear, nose and throat 5; pathology 3; public health 3; obstetrics I; hematology I; orthopedics I; proctology 2; dermatology 2, and neuropsychiatry 16.

Although these men were physicians in good standing and specialists in various branches of medicine, they did not designate themselves as psychiatrists, and were not qualified to give expert opinion, by either training or experience, on the mental status of the prisoners.

In order to remedy this situation, a bill has been introduced in the New York State legislature for the past three years which provides a procedure for the licensing by the.state of "qualified psychiatrists." To insure the utilization of the services of

son having two years postgraduate study in psychology at a university or college and three years of "actual clinical experience . . . shall be and become a qualified psychologist." Id. \$rg.

A number of other statutory provisions relate to the examination of mental condition of convicts. For the text of these and the above statutes, see New York State Law Revision Commission, Recommendations and Study made in relation to the Proposals of the Medical Jurisprudence Committee of the New York Academy of Medicine (r935) N. Y. LEcrs. Doc. No. 6o (L).

- Examination of alleged mental defectives is provided for by Section 125 of the Mental Hygiene Law, discussed supra note 3. Any physician in practice for three years may be certified as a "qualified examiner" under Section 19 of this law. 
psychiatrists so qualified, a companion bill has been introduced. amending Section 658 of the Code of Criminal Procedure, so that the composition of a lunacy commission shall consist of a lawyer and a qualified psychiatrist, the third member not being designated in a specific manner, but left to the discretion of the judge appointing the commission. ${ }^{5}$

The first bill ${ }^{6}$ provides for the creation in the department of mental hygiene of a board of psychiatric examiners "to consist of the state commissioner of mental hygiene, the head of the department of psychiatry or of neurology and psychiatry of a medical college in New York State who shall be appointed by the state commissioner of education, the state commissioner of correction and a physician selected by the council of the Medical Society of the State of New York. The state commissioner of mental hygiene may delegate an assistant commissioner of his department, and the commissioner of correction may delegate a competent psychiatrist of his department to appear and exercise their respective powers and duties at any meeting of the board."

The members of the board thus created are to receive no compensation but are to be reimbursed for their actual expenses. The board is given power to make necessary rules and regulations.

Authority is conferred on the board to give certificates as qualified psychiatrists to persons meeting the conditions prescribed in the statute as follows:

"No person shall receive a certificate unless

"(I) he is a physician duly licensed to practice in the state of New York and has had at least five years' experience in actual practice; and

"(2) either (a) has had three years' full time practice since January first, nineteen hundred fifteen, in the care and treatment of persons suffering from nervous and mental diseases or mental defects in an institution providing for the care of such persons and having accommodations for at least fifty, such patients, or

"(b) has devoted the five years immediately prior to filing his application for certification to a practice confined wholly or substantially to the care and treatment of persons suffering from nervous and mental diseases or mental defects; and

"(c) shall fulfill such additional requirements as may be established by the board from time to time to insure the competency of such person to act as a psychiatrist in any action or proceeding in which by any provision of law the services of a psychiatrist holding a certificate from the board are required."

The bill further provides that the department shall keep a record of the persons so certified and publish a list of such persons annually. Disciplinary powers over

${ }^{5}$ This bill undertakes an extensive revision not only of Section 658 but also of the succeeding scetions relating to the procedure to be followed upon the rendition of the commission's report. For the text of this bill and a discussion of the proposals contained in both bills, see New York State Law Revision Commission, supra note 3 .

As has been pointed out, supra note 3, Section 836 of the Code Criminal Procedure already provides for examination by a "qualified psychiatrist as provided by law" although no law as yet provides the qualifications of psychiatrists.

'N. Y. Assembly Bill Int. No. 784 (1933), providing for the insertion of a new section 27 in chapter 27, article 2, of the consolidated laws of New York. 
those certified is vested in the board by the concluding provision which reads as follows:

"If the board, after reasonable notice and an opportunity to be heard, finds that a certificate was obtained by misrepresentation or fraud, or is held by a person who is unfit or incompetent from negligence or other cause, to act as a psychiatrist in any action or proceeding in which by any provision of law the services of a certified psychiatrist are required, it may revoke or suspend for a fixed period, such certificate."

The bill for the qualification of experts has been approved by the New York Academy of Medicine, the Bar Association of the City of New York, the New York County Lawyers Association, the judges of the Court of General Sessions, the State Charities Aid Association and the Medical Society of the State of New York. It is the first time that the State Medical Society has agreed to a classification of its membership. Nevertheless, the bill has failed of adoption through opposition, perhaps because of a lack of complete understanding of its importance.

Not only is this measure significant by virtue of its immediate contribution to the problem of securing properly trained personnel for lunacy commissions in criminal cases; it is also likely to have a far-reaching effect on the caliber of expert witnesses employed in criminal and even civil cases where the issue of mental competency is raised. The psychiatrist who meets the standards established by the board will command the respect which his qualifications merit. The testimony of the unqualified "expert" will be accorded scant consideration. 